\title{
The intergenerational production of depression in South Korea: results from a cross-sectional study
}

\author{
B. G. Jeong ${ }^{1 *}$ and G. Veenstra ${ }^{2}$
}

\begin{abstract}
Background: Although a number of studies have uncovered relationships between parental capital and the manifestation of depression in their children, little is known about the mechanisms that undergird the relationships. This study investigates the intergenerational effects of the cultural and economic capitals of South Korean parents on depressive symptoms in their adult children and the degree to which the capitals of the adult children explain them.

Methods: We employed nationally representative cross-sectional survey data from the 2006 Korea Welfare Panel Study. A sample of 11,576 adults over thirty years of age was used to investigate the intergenerational production of depression in South Korea. We applied binary logistic regression modelling to the Center for Epidemiological Studies Depression Scale (CES-D).

Results: Parental education (institutionalized cultural capital) manifested an independent and statistically significant inverse association with depressive symptoms [OR $=1.680$ (95\% Cl: 1.118-2.523) for men; OR $=2.146$ (95\% Cl: 14843.102) for women]. Childhood economic circumstances (economic capital) had an independent and statistically significant inverse association with depressive symptoms among adult women only [OR $=2.009$ (95\% Cl: 1.531-2. 635)]. The education of the adult children themselves was strongly associated with depressive symptoms in the expected direction $[\mathrm{OR}=4.202$ (95\% Cl: 2.856-6.181) for men; $\mathrm{OR}=4.058$ (95\% Cl: 2.824-5.830)] and the most of the association between parental capitals and depressive symptoms was explained by the educational attainment of the children. Receipt of monetary inheritance from parents had a weak but statistically significant association with depression among men [OR $=1.248$ (95\% Cl: 1.041-1.496)] but was unrelated to depression among women. A large portion of the association between respondent education and depressive symptoms was explained by household income. Finally, childhood economic circumstances were associated with depressive symptoms among women over and above the cultural and economic capitals held by the women themselves [OR $=1.608$ (95\% Cl: 2.08-2.139)].
\end{abstract}

Conclusions: Our study illuminates the importance of the intergenerational transmission of capitals for the development of depressive symptoms among adults in South Korea.

Keywords: South Korea, Depressive symptoms, Capitals, Intergenerational processes

\footnotetext{
* Correspondence: jjbkkr@yahoo.co.kr

${ }^{1}$ Department of Preventive Medicine, School of Medicine \& Institute of

Health Science, Gyeongsang National University, 15, 816 Beon-Gil,

Jinjudae-Ro, Jinju-si, Gyeongsangnam-Do 660-751, South Korea

Full list of author information is available at the end of the article
} 


\section{Background}

Depression is a mood disorder characterized by overwhelmingly negative emotions and a sustained loss of pleasure [1-3]. At any given point in time, approximately one to three percent of the residents of industrialized countries experience persistent, recurring symptoms of depression $[4,5]$. Depression can have a dramatic effect on people's lives, impairing social, work and family functioning [6-8] and negatively affecting physical health and well-being [9].

Although a large body of research indicates that hereditary factors can predispose people to depression [10, 11], a growing body of evidence suggests that socioeconomic conditions are also important factors in the onset of depression. For instance, a number of studies have uncovered relationships between parental socioeconomic status and the manifestation of depression in their children $[12,13]$, associations that persist after controlling for parental depression $[14,15]$. Other studies have determined that the risk of depression among adults is higher among people with lower levels of education, less prestigious occupations and lower incomes [16-18].

Children and adults living in poor socioeconomic circumstances typically experience more stressful living conditions [19], possess relatively low levels of control over their physical and social environments [20], face more difficulties creating intimate relationships [21] and experience poorer health than do people living in good socioeconomic circumstances [22, 23]. These factors can increase a person's vulnerability to depression and reduce their ability to cope with it once manifested. In short, depression appears to be affected by socioeconomic circumstances at multiple stages of the life course.

However, the socioeconomic status of adults is shaped by the socioeconomic status of their parents [24-26], suggestive of a more complex causal storyline that runs from parental capitals to the capitals of the children and subsequently to the manifestation of depression in the children in adulthood. Capitals can be transmitted from parents to children through various processes. For instance, wealth can be directly transmitted to children by means of inheritance. Wealthier parents can also invest more money and time in educating their children. More highly educated parents have a greater capacity to develop linguistic and other cultural skills and talents in their children that can subsequently affect the latter's performance in the education system and in the labor market. In other words, the capital resources possessed by parents can be transmitted to the next generation through a variety of processes that effectively serve to reproduce socioeconomic inequality across generations. Accordingly, depression in adults may be partly reflective of intergenerational capital transmission processes from parents to children.
The plausibility of this multigenerational line of causality notwithstanding, empirical studies that relate processes of intergenerational transmission of capital to adult health are rare [27, 28]. In particular, research on the relationship between processes of intergenerational capital transmission and depression, an important domain of mental health, is nonexistent. To address this gap, we use cross-sectional survey data from the 2006 Korean Welfare Panel Study to investigate the degree to which the capitals of South Korean parents are related to the capitals of their adult children and, ultimately, to the manifestation of depressive symptoms in them.

\section{Methods \\ Data and study population}

Our study uses data from the 2006 wave of the Korea Welfare Panel Study which has a response rate of $71.3 \%$. We restricted our investigation to survey respondents $(n=12,292)$ who were thirty years of age or older at the time of the survey in order to produce stable measures of educational attainment. We further restricted our analyses to the 11,576 respondents ( $94.2 \%$ of the sample) who provided valid information for all of the variables used in our study. Table 1 describes characteristics of the latter sample.

\section{Measures \\ Cultural capital}

According to Bourdieu [29], cultural capital can exist in three forms. Cultural tastes and inclinations, a kind of embodied cultural capital, are lasting dispositions of mind and body. Objectified cultural capital refers to the possession of valued cultural goods. Institutionalized cultural capital is a "form of objectification which must be set apart because, as will be seen in the case of educational qualification, it confers entirely original properties on the cultural capital which it is presumed to guarantee" ([29], p. 248). In our study, respondents were asked about their mother and father's levels of educational attainment, measures of institutionalized cultural capital from which we created a single variable assessing parental highest level of education. We also assessed the institutionalized cultural capital of the survey respondents themselves in the form of personal highest level of educational attainment. Both variables distinguished between seven levels of education: did not complete elementary school, completed elementary school, completed middle school, completed high school, completed technical college, completed university and completed graduate school. For use in regression modelling, we combined the elementary school and middle school categories for both variables and the university and graduate school categories for the parental education variable. 
Table 1 Characteristics of the survey sample ( $n=11,576$; un-weighted data)

\begin{tabular}{|c|c|c|c|c|c|}
\hline \multirow[t]{2}{*}{ Variable } & \multirow[t]{2}{*}{ Categories } & \multicolumn{2}{|l|}{ Men } & \multicolumn{2}{|c|}{ Women } \\
\hline & & $n$ & $\%$ & $n$ & $\%$ \\
\hline \multirow[t]{3}{*}{ Age } & less than 40 & 1374 & 26.0 & 1430 & 22.7 \\
\hline & 40 to 59 & 2095 & 39.6 & 2293 & 36.5 \\
\hline & 60 and older & 1819 & 34.4 & 2565 & 40.8 \\
\hline \multirow[t]{5}{*}{ Marital status } & married & 4378 & 82.8 & 4294 & 68.3 \\
\hline & widowed & 151 & 2.9 & 1442 & 22.9 \\
\hline & separated & 52 & 1.0 & 82 & 1.3 \\
\hline & divorced & 218 & 4.1 & 268 & 4.3 \\
\hline & single & 489 & 9.3 & 202 & 3.2 \\
\hline \multirow[t]{7}{*}{ Highest parental education } & did not complete elementary school & 2280 & 43.1 & 2932 & 46.6 \\
\hline & elementary school & 1500 & 28.4 & 1617 & 25.7 \\
\hline & middle school & 585 & 11.1 & 709 & 11.3 \\
\hline & high school & 644 & 12.2 & 703 & 11.2 \\
\hline & technical college & 56 & 1.1 & 75 & 1.2 \\
\hline & university & 203 & 3.8 & 231 & 3.7 \\
\hline & graduate school & 20 & 0.4 & 21 & 0.3 \\
\hline \multirow[t]{5}{*}{ Economic conditions in childhood } & very poor & 566 & 10.7 & 581 & 9.2 \\
\hline & poor & 1899 & 35.9 & 1914 & 30.4 \\
\hline & average & 2228 & 42.1 & 2843 & 45.2 \\
\hline & rich & 542 & 10.3 & 859 & 13.7 \\
\hline & very rich & 53 & 1.0 & 91 & 1.5 \\
\hline \multirow[t]{7}{*}{ Educational attainment } & did not complete elementary school & 420 & 7.9 & 1485 & 23.6 \\
\hline & elementary school & 901 & 17.0 & 1373 & 21.8 \\
\hline & middle school & 658 & 12.4 & 782 & 12.4 \\
\hline & high school & 1792 & 33.9 & 1722 & 27.4 \\
\hline & technical college & 407 & 7.7 & 298 & 4.7 \\
\hline & university & 956 & 18.1 & 577 & 9.2 \\
\hline & graduate school & 154 & 2.9 & 51 & 0.8 \\
\hline \multirow[t]{2}{*}{ Received inheritance } & yes & 1452 & 27.5 & 960 & 15.3 \\
\hline & no & 3836 & 72.5 & 5328 & 84.7 \\
\hline \multirow[t]{11}{*}{ Household income } & $<1000$ & 1205 & 22.8 & 1985 & 31.6 \\
\hline & 1000-1999 & 1199 & 22.7 & 1418 & 22.6 \\
\hline & 2000-2999 & 972 & 18.4 & 998 & 15.9 \\
\hline & 3000-3999 & 680 & 12.9 & 654 & 10.4 \\
\hline & $4000-4999$ & 479 & 9.1 & 476 & 7.6 \\
\hline & $5000-5999$ & 246 & 4.7 & 246 & 3.9 \\
\hline & $6000-6999$ & 193 & 3.7 & 199 & 3.2 \\
\hline & 7000-7999 & 139 & 2.6 & 127 & 2.0 \\
\hline & 8000-8999 & 67 & 1.3 & 63 & 1.0 \\
\hline & 9000-999 & 33 & 0.6 & 38 & 0.6 \\
\hline & $>10000$ & 75 & 1.4 & 84 & 1.3 \\
\hline \multirow[t]{2}{*}{ Depressive symptoms } & few (0-8 on the CES-D) & 4154 & 78.6 & 4258 & 67.7 \\
\hline & regular ( 9 or more on the CES-D) & 1134 & 21.4 & 2030 & 32.3 \\
\hline
\end{tabular}




\section{Economic capital}

To assess parental economic capital, respondents were asked "What were your economic living conditions during childhood (0-17 years of age)?" with response categories 'very poor,' 'poor,' 'average,' 'rich' and 'very rich.' We combined the latter two categories for use in our regression analyses. The current household incomes of respondents were also calculated from a series of questions assessing income from multiple sources including employment, investments, pensions, social insurance, etc. Assessed in $10,000,000$ won units, this right-skewed continuous variable ranged from a low of zero to a high of 30.8. A categorical version of household income is described in Table 1. Respondents were also asked "Have you ever received an inheritance or donation from your parents?" to which they could reply 'yes' or 'no.'

\section{Depression}

Depression was measured by calculating the sum of 11 items derived from the Center for Epidemiological Studies Depression Scale (CES-D). The CES-D scale was developed to diagnose depression by way of assessing a range of depressive symptoms. This scale is a widely used measure of depression and several short CES-D forms have been developed from it [30, 31]. Each item was answered using a 4-point scale $(0=$ less than one day in the past week; 1 = two or three days in the past week; 2 =four or five days in the past week; $3=$ six or seven days in the past week). Cronbach's alpha for the 11 items from the CES-D scale in this sample was high at 0.88 . Consistent with previous research [32-34], respondents were categorized into two groups: few depressive symptoms $(72.7 \%$ of the sample scored $0-8$ on the CES-D) and regular depressive symptoms (27.3\% of the sample had a score of 9 or higher).

\section{Data analysis}

We created a series of binary logistic regression models on depression separately for men $(n=5288)$ and women $(n=6288)$. These models are described in Tables 2 and 3 . The first model in each table describes the effects of parental education and childhood economic circumstances on depression while controlling for age and marital status. The second model adds personal education to the first model, the third model adds receipt of inheritance money to the second model and the fourth model adds household income to the third model. This sequence of models enables us to identify the independent effects of parental cultural and economic capitals on depression and then investigate the degree to which various forms of capital held by the respondents potentially explain them. However, the problem of residual variance in logistic regression means that changes in regression coefficients across nested models can reflect changes in the scaling of the dependent variable [35]. Accordingly, we also applied the Karson/Holm/Breen (KHB) method of decomposing effects in non-linear probability models $[36,37]$ via the $k h b$ command in Stata [38] when investigating mediation. In all of our analyses we utilized the master weight variable provided with the Korea Welfare Panel Study to produce estimates that more closely represent the adult South Korean population.

\section{Results}

Model 1 in Table 2 and Model 1 in Table 3 indicate that parental education manifests an independent and statistically significant association with depression among men and among women. Childhood economic conditions have an independent and statistically significant association with depression among women only. ${ }^{1}$

Model 2 in Table 2 and Model 2 in Table 3 indicate that personal education has a strong association with depression for both men and women. The declines in the effect sizes of parental education from Model 1 to Model 2 in both tables suggest that much of the association between parental resources and depression is explained by personal educational attainment. The KHB decomposition indicates that $73.1 \%$ of the association between parental education (most versus least educated) and depression is caught up in the educational attainment of the men; for women this percentage is $62.0 \%$. A decline in the effect size of childhood economic conditions from Model 1 to Model 2 in Table 3 suggests that some of the association between childhood economic conditions and depression is explained by the educational attainment of the women; the KHB decomposition indicates that $30.1 \%$ of the association between childhood economic conditions (very poor versus rich or very rich) and depression is caught up in the educational attainment of the women (Additional file 1). However, childhood economic circumstances retain a statistically significant association with depression over and above the educational attainment of the respondents themselves, but only for women.

Model 3 of Table 2 indicates that receipt of inheritance from parents has a weak but statistically significant association with depression among men; inheritance is unrelated to depression among women. The fourth models in Tables 2 and 3 indicate that household income has a strong association with depression for both men and women, and the declines in effect size for respondent education from Model 3 to Model 4 in these tables suggest that some of the association between respondent education and depression is explained by respondent income. For men, the KHB decomposition indicates that $44.7 \%$ of the association between respondent education (most versus least educated) and depression is caught up 
Table 2 Binary logistic regression models on presence of depression in men (weighted data)

\begin{tabular}{|c|c|c|c|c|c|c|c|c|c|c|c|c|c|}
\hline \multirow{3}{*}{$\begin{array}{l}\text { Variable } \\
\text { Highest parental } \\
\text { education }\end{array}$} & \multirow{3}{*}{$\begin{array}{l}\text { Categories } \\
\text { did not complete } \\
\text { elementary school }\end{array}$} & \multicolumn{3}{|l|}{ Model 1} & \multicolumn{3}{|l|}{ Model 2} & \multicolumn{3}{|l|}{ Model 3} & \multicolumn{3}{|l|}{ Model 4} \\
\hline & & \multirow{2}{*}{$\begin{array}{l}\text { OR } \\
1.680 *\end{array}$} & \multicolumn{2}{|l|}{$95 \% \mathrm{Cl}$} & \multirow{2}{*}{$\begin{array}{l}\text { OR } \\
1.150\end{array}$} & \multicolumn{2}{|c|}{$95 \% \mathrm{Cl}$} & \multirow{2}{*}{$\begin{array}{l}\text { OR } \\
1.147\end{array}$} & \multicolumn{2}{|c|}{$95 \% \mathrm{Cl}$} & \multirow{2}{*}{$\begin{array}{l}\text { OR } \\
1.004\end{array}$} & \multicolumn{2}{|c|}{$95 \% \mathrm{Cl}$} \\
\hline & & & 1.118 & 2.523 & & 0.754 & 1.755 & & 0.752 & 1.750 & & 0.653 & 1.545 \\
\hline & $\begin{array}{l}\text { elementary or } \\
\text { middle school }\end{array}$ & $1.479 *$ & 1.004 & 2.179 & 1.180 & 0.793 & 1.757 & 1.176 & 0.790 & 1.750 & 1.079 & 0.720 & 1.616 \\
\hline & high school & 1.273 & 0.835 & 1.940 & 1.141 & 0.746 & 1.747 & 1.129 & 0.738 & 1.729 & 1.050 & 0.680 & 1.621 \\
\hline & technical college & 1.772 & 0.873 & 3.597 & 1.724 & 0.843 & 3.527 & 1.751 & 0.854 & 3.590 & 1.773 & 0.852 & 3.691 \\
\hline & $\begin{array}{l}\text { university } \\
\text { (reference) }\end{array}$ & 1.000 & & & 1.000 & & & 1.000 & & & 1.000 & & \\
\hline \multirow{4}{*}{$\begin{array}{l}\text { Economic } \\
\text { conditions in } \\
\text { childhood }\end{array}$} & very poor & 1.196 & 0.867 & 1.650 & 0.932 & 0.669 & 1.298 & 0.893 & 0.639 & 1.247 & 0.946 & 0.673 & 1.329 \\
\hline & poor & 1.035 & 0.801 & 1.337 & 0.906 & 0.698 & 1.176 & 0.874 & 0.672 & 1.137 & 0.924 & 0.707 & 1.209 \\
\hline & average & 0.863 & 0.672 & 1.109 & 0.836 & 0.649 & 1.076 & 0.823 & 0.639 & 1.060 & 0.845 & 0.653 & 1.093 \\
\hline & $\begin{array}{l}\text { rich or very rich } \\
\text { (reference) }\end{array}$ & 1.000 & & & 1.000 & & & 1.000 & & & 1.000 & & \\
\hline \multirow[t]{5}{*}{$\begin{array}{l}\text { Educational } \\
\text { attainment }\end{array}$} & $\begin{array}{l}\text { did not complete } \\
\text { elementary school }\end{array}$ & & & & $4.202^{* * *}$ & 2.856 & 6.181 & $4.165^{* * *}$ & 2.832 & 6.126 & $2.356^{* * *}$ & 1.584 & 3.502 \\
\hline & $\begin{array}{l}\text { elementary or } \\
\text { middle school }\end{array}$ & & & & $2.655^{* * *}$ & 2.048 & 3.441 & $2.634^{* * *}$ & 2.033 & 3.414 & $1.670^{* * *}$ & 1.274 & 2.190 \\
\hline & high school & & & & $1.583^{* * *}$ & 1.269 & 1.974 & $1.571^{* * *}$ & 1.259 & 1.960 & 1.171 & 0.932 & 1.471 \\
\hline & technical college & & & & $1.649 * *$ & 1.211 & 2.245 & $1.650 * *$ & 1.212 & 2.246 & 1.312 & 0.957 & 1.797 \\
\hline & $\begin{array}{l}\text { university } \\
\text { (reference) }\end{array}$ & & & & 1.000 & & & 1.000 & & & 1.000 & & \\
\hline \multirow{2}{*}{$\begin{array}{l}\text { Received } \\
\text { inheritance }\end{array}$} & no & & & & & & & $1.248 *$ & 1.041 & 1.496 & $1.270 *$ & 1.056 & 1.526 \\
\hline & yes (reference) & & & & & & & 1.000 & & & 1.000 & & \\
\hline $\begin{array}{l}\text { Household } \\
\text { income }\end{array}$ & $\ldots$ & & & & & & & & & & $0.687 * * *$ & 0.644 & 0.734 \\
\hline $\begin{array}{l}\text { Household } \\
\text { income squared }\end{array}$ & $\ldots$ & & & & & & & & & & $1.013 * * *$ & 1.010 & 1.017 \\
\hline $\begin{array}{l}\text { Hosmer and } \\
\text { Lemeshow test }\end{array}$ & & $\begin{array}{l}x 2=7.087 \\
(p=0.527)\end{array}$ & & & $\begin{array}{l}x 2=4.268 \\
(p=0.832)\end{array}$ & & & $\begin{array}{l}x 2=10.281 \\
(p=0.246)\end{array}$ & & & $\begin{array}{l}x 2=27.638 \\
(p=0.001)\end{array}$ & & \\
\hline-2 log likelihood & & 4597.925 & & & 4524.390 & & & 4518.519 & & & 4367.795 & & \\
\hline
\end{tabular}

Each model controls for age, square of age, and marital status. $N=5288$ in each model. ${ }^{*} p<0.05,{ }^{* *} p<0.01,{ }^{* * *} p<0.001$

in the incomes of the respondents; for women this percentage is $42.7 \%$ (Additional file 1).

Lastly, Model 4 in Tables 3 and 4 indicate that the economic capital of parents manifests a statistically significant association with depressive symptoms in the respondents over the capitals held by the respondents themselves for women but not for men.

\section{Discussion}

We find that personal educational attainment and household income are both strongly and negatively related to depressive symptoms in our representative sample of South Korean adults. These findings are consistent with previous research in South Korea [39-41]. Plausible explanations for these associations are that higher education can foster intellectual and coping skills that serve as protective factors against depression $[15,18]$, high income reduces debilitating financial stressors that can contribute to the onset of depression [42] and well-paying jobs afford greater social prestige and better psychosocial and physical working conditions which in turn can be protective against depression [43].

We also find that a third or more of the association between the educational attainment of respondents and depressive symptoms is potentially mediated by household income. This is an example of what have been elsewhere referred to as capital conversions [44] or capital acquisition interplays [28], social processes whereby one form of capital facilitates the successful acquisition of another form of capital and consequently good health. In this case, institutionalized cultural capital in the form of educational credentials is presumably used by men and women to procure high-paying jobs (or spouses with high-paying jobs) and amass financial wealth which then mitigate the development of depressive symptoms. 
Table 3 Binary logistic regression models on presence of depression in women (weighted data)

\begin{tabular}{|c|c|c|c|c|c|c|c|c|c|c|c|c|c|}
\hline \multirow{3}{*}{$\begin{array}{l}\text { Variable } \\
\text { Highest parental } \\
\text { education }\end{array}$} & \multirow{3}{*}{$\begin{array}{l}\text { Categories } \\
\text { did not complete } \\
\text { elementary school }\end{array}$} & \multicolumn{3}{|l|}{ Model 1} & \multicolumn{3}{|l|}{ Model 2} & \multicolumn{3}{|l|}{ Model 3} & \multicolumn{3}{|l|}{ Model 4} \\
\hline & & \multirow{2}{*}{$\begin{array}{l}\mathrm{OR} \\
2.146^{* * *}\end{array}$} & \multicolumn{2}{|c|}{$95 \% \mathrm{Cl}$} & \multirow{2}{*}{$\begin{array}{l}\mathrm{OR} \\
1.331\end{array}$} & \multicolumn{2}{|c|}{$95 \% \mathrm{Cl}$} & \multirow{2}{*}{$\begin{array}{l}\text { OR } \\
1.324\end{array}$} & \multicolumn{2}{|c|}{$95 \% \mathrm{Cl}$} & \multirow{2}{*}{$\begin{array}{l}\text { OR } \\
1.226\end{array}$} & \multicolumn{2}{|c|}{$95 \% \mathrm{Cl}$} \\
\hline & & & 1.484 & 3.102 & & .901 & 1.967 & & .896 & 1.957 & & .824 & 1.824 \\
\hline & $\begin{array}{l}\text { elementary or middle } \\
\text { school }\end{array}$ & $1.725 * *$ & 1.211 & 2.456 & 1.238 & .856 & 1.791 & 1.232 & .851 & 1.784 & 1.163 & .798 & 1.694 \\
\hline & high school & $1.710 * *$ & 1.172 & 2.494 & 1.378 & .937 & 2.028 & 1.373 & .933 & 2.022 & 1.319 & .889 & 1.955 \\
\hline & technical college & 1.165 & .606 & 2.238 & 1.067 & .549 & 2.073 & 1.065 & .548 & 2.071 & .906 & .465 & 1.767 \\
\hline & university (reference) & 1.000 & & & 1.000 & & & 1.000 & & & 1.000 & & \\
\hline \multirow{4}{*}{$\begin{array}{l}\text { Economic } \\
\text { conditions in } \\
\text { childhood }\end{array}$} & very poor & $2.009 * * *$ & 1.531 & 2.635 & 1.637 ** & 1.237 & 2.166 & 1.627 ** & 1.228 & 2.155 & 1.608 ** & 1.208 & 2.139 \\
\hline & poor & 1.200 & .979 & 1.470 & 1.059 & .860 & 1.303 & 1.054 & .855 & 1.298 & 1.134 & .918 & 1.402 \\
\hline & average & .978 & .807 & 1.186 & .940 & .774 & 1.141 & .936 & .770 & 1.137 & .995 & .816 & 1.214 \\
\hline & $\begin{array}{l}\text { rich or very rich } \\
\text { (reference) }\end{array}$ & 1.000 & & & 1.000 & & & 1.000 & & & 1.000 & & \\
\hline \multirow[t]{5}{*}{$\begin{array}{l}\text { Educational } \\
\text { attainment }\end{array}$} & $\begin{array}{l}\text { did not complete } \\
\text { elementary school }\end{array}$ & & & & $4.058 * * *$ & 2.824 & 5.830 & $4.031^{* * *}$ & 2.803 & 5.796 & $2.260 * * *$ & 1.551 & 3.293 \\
\hline & $\begin{array}{l}\text { elementary or middle } \\
\text { school }\end{array}$ & & & & $2.481 * * *$ & 1.844 & 3.339 & $2.468 * * *$ & 1.833 & 3.324 & $1.557 * *$ & 1.142 & 2.121 \\
\hline & high school & & & & $2.066^{* * *}$ & 1.607 & 2.656 & $2.059 * * *$ & 1.601 & 2.648 & $1.574^{* *}$ & 1.216 & 2.038 \\
\hline & technical college & & & & 1.056 & .716 & 1.558 & 1.054 & .714 & 1.555 & .873 & .589 & 1.295 \\
\hline & university (reference) & & & & 1.000 & & & 1.000 & & & 1.000 & & \\
\hline \multirow{2}{*}{$\begin{array}{l}\text { Received } \\
\text { inheritance }\end{array}$} & no & & & & & & & 1.052 & .875 & 1.266 & 1.052 & .873 & 1.269 \\
\hline & yes (reference) & & & & & & & 1.000 & & & 1.000 & & \\
\hline $\begin{array}{l}\text { Household } \\
\text { income }\end{array}$ & $\ldots$ & & & & & & & & & & $.732 * * *$ & .693 & .774 \\
\hline $\begin{array}{l}\text { Household } \\
\text { income squared }\end{array}$ & $\ldots$ & & & & & & & & & & $1.010 * * *$ & 1.007 & 1.014 \\
\hline $\begin{array}{l}\text { Hosmer and } \\
\text { Lemeshow test }\end{array}$ & & $\begin{array}{l}x 2=10.247 \\
(p=0.248)\end{array}$ & & & $\begin{array}{l}x 2=14.232 \\
(p=0.076)\end{array}$ & & & $\begin{array}{l}x 2=18.322 \\
(p=0.019)\end{array}$ & & & $\begin{array}{l}x 2=12.817 \\
(p=0.118)\end{array}$ & & \\
\hline $\begin{array}{l}-2 \log \\
\text { likelihood }\end{array}$ & & 6029.167 & & & 5957.404 & & & 5957.110 & & & 5794.076 & & \\
\hline
\end{tabular}

Each model controls for age, square of age, and marital status. $N=6288$ in each model. ${ }^{*} p<0.05,{ }^{* *} p<0.01,{ }^{* * *} p<0.001$

In regards to intergenerational processes, we find that monetary inheritances or gifts from parents correspond with a lesser risk of depression for men. This is an example of what Veenstra and Abel [28] refer to as capital transmission processes, social processes whereby the capital of one party is transmitted to another person and then generates good health in the recipient. The absence of an association between inheritance and depressive symptoms among women may reflect the fact that monetary inheritances in South Korea tend to be much larger for sons than for daughters [45]. The largest transfer of financial assets from parents to children typically occurs when children marry. The parents of the groom often provide substantial economic support in the form of a house while the parents of the bride often provide household items. Unfortunately, our blunt measure of monetary inheritance does not allow us to empirically investigate the importance of the differential magnitude of inheritances for the mental health of men and women.
Finally, we find strong associations between parental educational capital and depressive symptoms among both men and women, associations that are almost entirely explained by the educational attainment of the adult children. In this case, we contend that parents strategically use their cultural capital to facilitate the acquisition of educational credentials by their children. In South Korea, educational qualifications virtually determine a person's economic status in adulthood [46, 47] and, accordingly, South Korean parents are inclined to invest hugely in the education of their children. Our study indicates that this strategy tends to pay off in the positive mental health of their children later in life.

Our study has several limitations. First, the analysis utilizes cross-sectional data and as such causality cannot be confidently ascertained. Second, the measures of parental cultural capital and economic capital used in our study are based on respondent recall, an issue of measurement that may be especially problematic for older 
adults. Third, our measure of parental economic capital is a subjective judgement on the part of the adult children rather than an objective assessment of parental wealth. As a result we may have misrepresented, perhaps even underrepresented, the true nature of the association between parental economic capital and respondent depression. Fourth, our measure of monetary inheritance does not assess the magnitude of inheritances. Fifth, obtaining a degree from a prestigious university is an extremely important indicator of institutionalized cultural capital in South Korea. Unfortunately, the Korean Welfare Panel Study did not ask university educated survey respondents to identify the universities from which they obtained their degrees. In spite of these limitations, our study is the first, to our knowledge, that measures the parental economic capitals using economic conditions in childhood, monetary inheritance to investigate the intergenerational effects of the parental capitals on depressive symptoms in their adult children and the degree to which the capitals of the adult children explain them.

\section{Conclusions}

Our study provides evidence for the intergenerational production of inequalities in depression in South Korea, findings that are consistent with studies conducted in the United States [12] and Finland [48]. Parental capitals are used to shape the accumulation of capitals by children, processes that militate against intergenerational mobility in South Korean society and ultimately produce inequalities in depression. In other words, socioeconomic inequalities in depression reflect a kind of social heredity in the accumulation of capitals in South Korean society.

\section{Endnotes}

${ }^{1}$ In supplementary analyses, multinomial and ordered logistic regression models which distinguish between CES-D scores of $0,1-8$, and 9 or higher did not improve upon models that simply distinguish between CES-D scores of $0-8$ and 9 or higher.

\section{Additional file}

Additional file 1: The KHB results. (DOCX $232 \mathrm{~kb}$ )

\section{Abbreviations}

CES-D: Center for Epidemiological Studies Depression Scale; KHB decomposition: Karson/Holm/Breen decomposition; KHB method: Karson/ Holm/Breen method

\section{Acknowledgements}

None.

\section{Funding}

Not applicable.

\section{Availability of data and materials}

These datasets were derived from the following public domain resources: [Korea Welfare Panel Study, https://www.koweps.re.kr:442/data/data/list.do].

\section{Authors' contributions}

This study received no external funding. BJ developed the idea and participated in the design of the study and interpretation of results and conducted the statistical analyses. GV participated in the design of the study and interpretation of results and drafted the manuscript. Both authors read and approved the final manuscript.

\section{Competing interests}

The authors declare that they have no competing interests.

\section{Consent for publication}

Not applicable.

\section{Ethics approval and consent to participate}

Ethical approval was not necessary since it is a secondary analysis of a public use database (https://www.koweps.re.kr:442/main.do) with anonymous data.

\section{Author details}

${ }^{1}$ Department of Preventive Medicine, School of Medicine \& Institute of Health Science, Gyeongsang National University, 15, 816 Beon-Gil, Jinjudae-Ro, Jinju-si, Gyeongsangnam-Do 660-751, South Korea. ${ }^{2}$ Department of Sociology, University of British Columbia, 6303 NW Marine Drive, Vancouver, BC V6T 1Z1, Canada.

Received: 2 August 2016 Accepted: 28 December 2016 Published online: 13 January 2017

\section{References}

1. Penninx BW, Deeg DJ, van Eijk JT, Beekman AT, Guralnik JM. Changes in depression and physical decline in older adults: a longitudinal perspective. J Affect Disord. 2000;61(1-2):1-12.

2. Simon GE, Barber C, Birnbaum HG, Frank RG, Greenberg PE, Rose RM, et al. Depression and work productivity: the comparative costs of treatment versus non treatment. J Occup Environ Med. 2001;43(1):2-9.

3. Kane $P$, Garber J. The relations among depression in fathers, children's psychopathology, and father-child conflict: a meta-analysis. Clin Psychol Rev. 2004;24(3):339-60.

4. Kessler RC, Berglund P, Demler O, Jin R, Koretz D, Merikangas KR, et al. The epidemiology of major depressive disorder: results from the National Comorbidity Survey Replication (NCS-R). JAMA. 2003;289:3095-105.

5. Hardeveld F, Spijker J, de Graaf R, Nolen WA, Beekman AT. Prevalence and predictors of recurrence of major depressive disorder in the adult population. Acta Psychiatr Scand. 2010;122:184-91.

6. Gorlmaker SL, Must A, Perrin JM, Sobol AM, Dietz WH. Social and economic consequences of overweight in adolescence and young adulthood. N Engl J Med. 1993;329(14):1008-12.

7. Must A, Spadano J, Coakley EH, Field AE, Colditz G, Dietz WH. The disease burden associated with overweight and obesity. JAMA. 1999;282(16):1523-9.

8. Weissman MM, Wolk S, Goldstein RB, Moreau D, Adams P, Greenwald S, et al. Depressed adolescents grown up. JAMA. 1999;281(18):1707-13.

9. Scott J. Depression should be managed like a chronic disease clinicians need to move beyond ad hoc approaches to isolated acute episodes. BMJ. 2006:332:985-6.

10. Weissman MM, Warner $V$, Wichramaratne P, Moreau D, Olfson M. Offspring of depressed parents: 10 years later. Arch Gen Psychiatry. 1997;54(10):932-40.

11. Catthoor K, Schrijvers D, Hutsebaut J, Feenstra D, Persoons P, De Hert M, et al. Associative stigma in family members of psychotic patients in Flanders: An exploratory study. World J Psychiatry. 2015;5(1):118-25.

12. Gilman SE, Kawachi I, Fitzmaurice GM, Buka L. Socio-economic status, family disruption and residential stability in childhood: relation to onset, recurrence and remission of major depression. Psychol Med. 2003;33(8):1341-55.

13. Goodman E, Slap GB, Huang B. The public health impact of socioeconomic status on adolescent depression and obesity. Am J Public Health. 2003; 93(11):1844-50.

14. Johnson JG, Cohen P, Dohrenwend BP, Link BG, Brook JS. A longitudinal investigation of social causation and social selection processes involved in 
the association between socioeconomic status and psychiatric disorders. J Abnorm Psychol. 1999;108(3):490-9.

15. Ritsher JE, Warner V, Johnson JG, Dohrenwend BP. Inter-generational longitudinal study of social class and depression: a test of social causation and social selection models. Br J Psychiatry. 2001;40(Suppl):84-90.

16. Turner RJ, Blair W, Lloyd Donald A. The epidemiology of social stress. Am Sociol Rev. 1995;60:104-25.

17. Weich S, Lewis G, Jenkins SP. Income inequality and the prevalence of common mental disorders in Britain. Br J Psychiatry. 2001;178:222-7.

18. Lorant V, Deliège D, Eaton W, Robert A, Philippot P, Ansseau M. Socioeconomic inequalities in depression: a meta-analysis. Am J Epidemiol. 2003;157:98-112.

19. Evans GW, Kim P. Childhood poverty, chronic stress, self-regulation, and coping. Child Dev Perspect. 2013;7(1):43-8.

20. Abramson LY, Seligman ME, Teasdale JD. Learned helplessness in humans: critique and reformulation. J Abnorm Psycho. 1978:87(1):49-74.

21. Mickelson KD, Kessler RC, Shaver PR. Adult attachment in a nationally representative sample. J Pers Soc Psychol. 1997;73(5):1092-106.

22. Adler NE, Stewart J. Health disparities across the lifespan: Meaning, methods, and mechanisms. Ann N Y Acad Sci. 2010;1186:5-23.

23. Kraus MW, Adler N, Chen TW. Is the association of subjective SES and self-rated health confounded by negative mood? An experimental approach. Health Psychol. 2013;32(2):138-45.

24. Carvalho L. Childhood circumstances and the intergenerational transmission of socioeconomic status. Demogr. 2012;49(3):913-38.

25. Case A, Fertig A, Paxson C. The lasting impact of childhood health and circumstance. J Health Econ. 2005;24:365-89.

26. Currie J. Healthy, wealthy, and wise: Socioeconomic status, poor health in childhood, and human capital development. J Econ Lit. 2009;47:87-122.

27. Eriksson T, Pan J, Qin X. The intergenerational inequality of health in China. China Econ Rev. 2014:31:392-409.

28. Veenstra G, Abel T. Capital interplays and the self-rated health of young men: Results from a cross-sectional study in Switzerland. Int J Equity Health. 2015;14(38):1-10.

29. Bourdieu P. The forms of capital. In: Richardson J, editor. Handbook of theory and research for the sociology of education. New York: Greenwood Press; 1986. p. 241-58.

30. Radloff LS. The CES-D scale a self-report depression scale for research in the general population. Appl Psychol Measur. 1977;1(3):385-401.

31. Demirkan A, Lahti J, Direk N, Viktorin A, Lunetta KL, Terracciano A, et al. Somatic, positive and negative domains of the Center for Epidemiological Studies Depression (CES-D) scale: a meta-analysis of genome-wide association studies. Psychol Med. 2016;46(8):1613-23.

32. Wolinsky FD, Andresen EM, Malmstrom TK, Schootman M, Miller JP, Miller DK. Three-year measured weight change in the African American health study. J Aging Health. 2009;21(2):231-43.

33. Malmstrom TK, Andresen EM, Wolinsky FD, Schootman M, Miller JP, Miller DK. Urinary and fecal incontinence and quality of life in African Americans. J Am Geriatr Soc. 2010;58(10):1941-5.

34. Harada N, Takeshita J, Ahmed I, Chen R, Petrovitch H, Ross GW, et al. Does cultural assimilation influence prevalence and presentation of depressive symptoms in older Japanese American men? The Honolulu-Asia aging study. Am J Geriatr Psychiatry. 2012;20(4):337-45.

35. Mood C. Logistic regression: Why we cannot do what we think we can do and what we can do about it. Eur Sociol Rev. 2010;26(1):67-82.

36. Karlson KB, Holm A, Breen R. Comparing regression coefficients between same-sample nested models using logit and probit. A new method. Sociol Methodol. 2011;42:286-313

37. Karlson KB, Holm A. Decomposing primary and secondary effects: a new decomposition method. Res Soc Stratif Mobil. 2011;29:221-37.

38. Kohler U, Karlson KB, Holm A. Comparing coefficients of nested nonlinear probability models. Stata J. 2011;11(3):420-38.

39. Kim H, Kim B. A path analysis of suicidal ideation in the elderly. Korean Couns Psychother. 2007;19(3):801-18 [in Korean]

40. Lee SR, Lee SA. Poverty status transition and mental health: the effect of mental health on the poverty status transition. Korean J Soc Welf Stud. 2010;41(4):277-311 [in Koean].

41. Kwon TH. Socioeconomic status and the trajectory in depressive symptoms - The mediating role of alcohol use. Korean J Health Educ Promot. 2012; 29(1):59-72 [in Korean].
42. Zimmerman FJ, Katon W. Socioeconomic status, depression disparities, and financial strain: what lies behind the income depression relationship? Health Econ. 2005;14:1197-215.

43. Zimmerman FJ, Christakis DA, Vander SA. Tinker, tailor, soldier, patient: work attributes and depression disparities among young adults. Soc Sci Med. 2004:58:1889-901

44. Abel T, Frohlich KL. Capitals and capabilities: Linking structure and agency to reduce health inequalities. Soc Sci Med. 2012;74:236-44.

45. Kim Y. A study of experiences, plans, and perception on the housing wealth transfer. J Korean Manag Assoc. 2012;30(2):11-26 [in Korean].

46. Sorensen CW. Success and education. Com Educ Rev. 1994:38:10-35.

47. Lee S, Brinton MC. Elite education and social capital: the case of South Korea. Sociol Educ. 1996:69:177-92.

48. Korhonen K, Remes H, Martikainen P. Education as a social pathway from parental socioeconomic position to depression in late adolescence and early adulthood: a Finnish population-based register study. Soc Psychiatry Psychiatr Epidemiol. 2016. doi:10.1007/s0012701612962.

\section{Submit your next manuscript to BioMed Central and we will help you at every step:}

- We accept pre-submission inquiries

- Our selector tool helps you to find the most relevant journal

- We provide round the clock customer support

- Convenient online submission

- Thorough peer review

- Inclusion in PubMed and all major indexing services

- Maximum visibility for your research

Submit your manuscript at www.biomedcentral.com/submit
) Biomed Central 